\title{
Assessment of Innovation Potential of Gayo Coffee Agroindustry
}

\author{
DOI: 10.12776/QIP.V21I3.888
}

\author{
Rahmat Fadhil, M. Syamsul Maarif, Tajuddin Bantacut, Aji Hermawan
}

\begin{abstract}
Purpose: The purpose of this study is to perform an assessment on the innovation potential of Gayo coffee agroindustry, as a basis of policymaking as an effort to promote agroindustry and to increase the revenue.

Methodology/Approach: Innovation potential assessment was performed with "Map of the Company Innovation Potential" through a stakeholder survey by using questionnaire and confirmation.
\end{abstract}

Findings: The result of the study shows that innovation potential of Gayo coffee agroindustry is good enough to be developed by considering today's reality and condition, based on innovation potential assessment that had been performed. This condition is very possible for the development of innovation activity in the form of work and the agroindustry program of Gayo coffee becomes more serious concern, so that the potential of innovation improvement can continue to grow and evolve by involving various parties to create a synergy in supporting innovation development.

Research Limitation/implication: This study describes the condition of innovation potential of Gayo coffee agroindustry in six aspects of assessment, which are: strategy and planning, marketing, technological process, quality and environment, logistic and human resources.

Originality/Value of paper: This article is according to field data from an interview with the stakeholders, field trip, and quantitative analysis. This study is very helpful for the policy maker in expanding Gayo coffee agroindustry, and become a contribution to analyze innovation potential in other agroindustry.

Category: Research paper

Keywords: agroindustry; Gayo coffee; assessment; innovation potential 


\section{INTRODUCTION}

The concept of regional expansion that is most relevant in $21^{\text {st }}$ century is through a concept of expansion based on technology and innovation, whose one of the indicators is the human resources capacity. Technology and innovation are main strength in order for the efficiency in agricultural to occurs that is seen from the comparison of the input and output (Mosher, 1966; Alkadri, 1999). A form of intervening changes in society and industry is process of innovation transfer. This process can go through the diffusion of innovation that is communicated to various channels in a certain period and in a certain system. By this diffusion of innovation, it is expected for the innovation adoption to occur so the capacity and competency of human resources will increase along with the ability to adopt the introduced innovation (Rogers, 2003). Process of policy making of innovation is a process where an individual receives a foreknowledge of an innovation to form an attitude towards the innovation, to make a decision; whether to adopt or to refuse, the performance of new idea, and to confirm the decision that will be implemented.

A systematic innovation management is a main supporter to increase the competitiveness of small and medium-scale industry. The successful realization of vision and innovation strategy in business practice is subject to conditions existence which is determining related innovation activity (Sabadka, 2012; Špaček and Štěpán, 2013). MERIT Centre (Maastricht Economic and Social Research and Training Centre on Innovation and Technology) published a study about innovation in the member state of the European Union (MERIT, 2008). Nevertheless, most of studies and literatures are focused on the companies as the generator of innovation. Every company has potential to become creative and innovative. According to Goffin and Mitchell (2005), the key of innovation is the changes in client (customer) needs, the changes in business environment, the increased in competition, and new technology.

Practically, today's study of innovation is focused on the assessment of innovation or audit of innovation and innovation management. In the process of designing company's strategy, it is important for the top management to get used to prioritize the competitive excellence of the company in the field of innovations. Thus, innovation is not only about producing creative business ideas, but it is about paying more attention on the idea by identifying people that is possible to become a success innovator. Unfortunately, many companies and organizations make mistakes in refusing an idea that is potentially innovative and even supporting other ideas that are less innovative (Baumgartner, 2010).

Assessment of innovation potential is important for the continuity of an industry, that various studies had been developed in various methods to find a way of how to measure the potential level of an innovation. Several studies about innovation potential, among others are, matrix of innovation potential (Sabadka, 2012), evaluating innovation potential through the measurement of innovation behavior in company (Jiřinová and Scholleová, 2015), measuring value of innovation 
potential in an organization in India (Khanapuri, Soni and Sharma, 2011), assessing innovation potential in the development of regional business environment in Russia (Parshukov, et al., 2015; Zemstov, 2014), strengthening value innovation potential with industrial orientation in Taiwan (Chang, 2013), agricultural innovation and new business by assessing commercial potential (Gray, et al., 2004), evaluating innovation idea (Baumgartner, 2010), concept of service innovation in United States (Ezell, Ogilvie and Rae, 2007), identification of innovation and innovator with high potential in the field of information, communication, and technology, competition program and innovation framework, also horizon 2020 of European Union (De Prato, Nepelski and Piroli, 2015), and assessing innovation potential of company in Romania (Scarlat, Alexe and Scarlet, 2011).

Agroindustry of Gayo coffee in Aceh province-Indonesia is one of businesses that is important in improving the community economy in that region, particularly in coffee Gayo-producing region, which are Central Aceh Regency, Bener Meriah Regency, and Gayo Lues Regency. Gayo is a name of a highland that is located in Bukit Barisan Mountain whose region is administratively located in Aceh province, and involving the three regencies mentioned above. However, regions that are dominant in producing Gayo coffee are only two regencies; Central Aceh Regency and Bener Meriah Regency. Coffee plants in this area has been existed since 1908, and now it reaches 81,000 hectares of coffee plantation (Putri, Fariyani and Kusnadi, 2013).

Gayo coffee is usually exported to the member state of European Union, United States, and Japan in the form of coffee beans or green bean (ICCRI, 2008; Silitonga, 2008). In the International Coffee Organization Report (2011) it mentioned that the trend of Gayo coffee trading to the importing countries is increasing. This condition is in accordance with the increased trend of Arabica coffee demand in world market that reaches $0.5 \%$ per year.

One important aspect in promoting agroindustry is by developing technology and innovation, because technology is a system that is closely linked to the engineering context from several fields of science appropriately to increase the value-added of the product resulted, while innovation is defined as an idea, method, practice, or product (goods and services) that is perceived as novelty by a unit for adoption (Rogers, 2003). The presence of technology and innovation certainly need an excellent implementation by the user community (Maulana, 2013).

The purpose of the study is to perform innovation potential assessment of Gayo coffee agroindustry as a model for the development of coffee industry in Indonesia for the increasing in revenue and better competitiveness. 


\section{METHODOLOGY}

One method that is more complete in assessing innovation potential is the one that was developed by Vacek, et al. (2001). They developed an indicator for innovation potential that is called as "Map of the Company Innovation Potential" and had been applied in assessing innovation in a manufacturing industry. Based on the method, authors made an adjustment to be applied in assessing innovation potential in agroindustry (agricultural industry). To evaluate innovation potential, a questionnaire guide was comprehensively designed, covering 6 aspects as assessment criteria (Fig. 1). In each aspect, there are 6 questions with 4 answer choices with ordinal scale; strongly agree, agree, disagree, or strongly disagree.

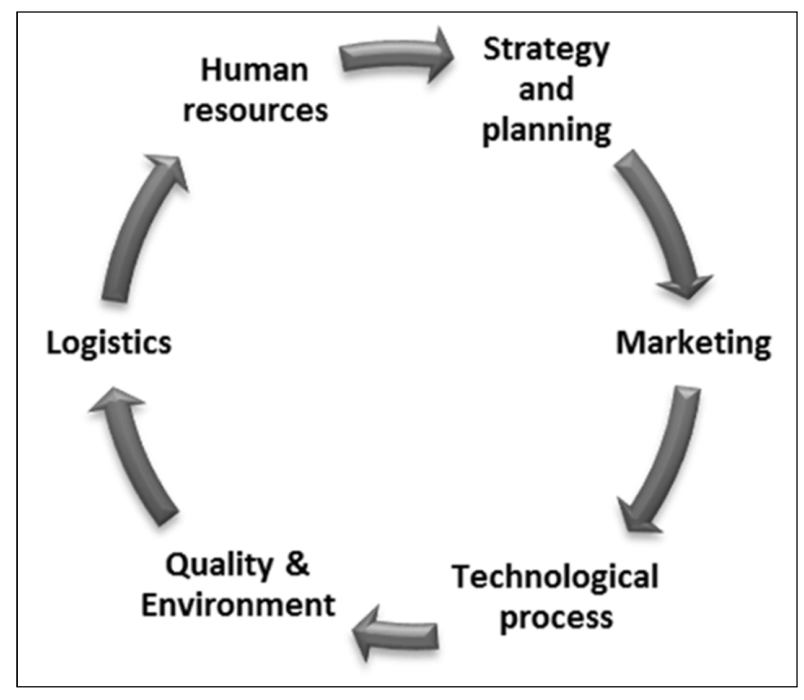

Figure 1 - Innovation Potential Assessment Framework

\subsection{Procedure of Research}

The prepared questionnaire covers several groups that are interrelated to assess company's innovation potential (Tab. 1). Questionnaires is to describe the situation of the Gayo coffee company (agroindustry) in general in Aceh province-Indonesia by assessing the level of high and low state of the company to create an environment for developing the innovation effectively. This includes how a company able to implement innovation in its various activity. The purpose of this innovation activity is a part of effort to increase customer's and other stakeholder's satisfaction. The final result will be classified in four classes (Tab. 2). 
Table 1 - Assessment Aspects and Questions Object (Adopted from Vacek, et al., 2001)

\begin{tabular}{|c|c|}
\hline Assessment Aspects & Questions Object \\
\hline \multirow[t]{6}{*}{ Strategy and planning } & 1. Idea about the future of agroindustry \\
\hline & 2. Vision and worker \\
\hline & 3. Agroindustry innovation program \\
\hline & 4. Modification of planning \\
\hline & 5. Planning of financial indicator \\
\hline & 6. Project management \\
\hline \multirow[t]{6}{*}{ Marketing } & 1. Monitoring current market trends \\
\hline & 2. Evaluating market competition position \\
\hline & 3. Customer's orientation \\
\hline & 4. Monitoring customer's respond towards the product \\
\hline & 5. Market information flow \\
\hline & 6. Marketing and financial control \\
\hline \multirow[t]{6}{*}{ Technological process } & 1. Future agroindustry competition \\
\hline & 2. Changes in technology use \\
\hline & 3. Collecting stimulation to perform technology change \\
\hline & $\begin{array}{l}\text { 4. Evaluating the return of investment in accordance with the } \\
\text { planned changes. }\end{array}$ \\
\hline & $\begin{array}{l}\text { 5. Calculating production cost and continuous monitoring in the } \\
\text { company }\end{array}$ \\
\hline & 6. Creating resources for development \\
\hline \multirow[t]{6}{*}{$\begin{array}{l}\text { Quality and } \\
\text { Environment }\end{array}$} & $\begin{array}{l}\text { 1. Monitoring the changes in quality management condition in } \\
\text { company }\end{array}$ \\
\hline & $\begin{array}{l}\text { 2. Evaluating individual contribution to the quality system in } \\
\text { company }\end{array}$ \\
\hline & 3. Quality of external audit in company \\
\hline & $\begin{array}{l}\text { 4. Monitoring the activity as the company's effect to the } \\
\text { environment. }\end{array}$ \\
\hline & $\begin{array}{l}\text { 5. Effect of the quality monitoring on the change process in the } \\
\text { company. }\end{array}$ \\
\hline & $\begin{array}{l}\text { 6. Resources creation to the cost resulted from the modification of } \\
\text { standards, regulations, and law in the field of quality and } \\
\text { environment. }\end{array}$ \\
\hline Logistics & $\begin{array}{l}\text { 1. Organizing the purchasing and the distribution channel in } \\
\text { company }\end{array}$ \\
\hline
\end{tabular}




\begin{tabular}{|c|c|}
\hline Assessment Aspects & Questions Object \\
\hline & 2. Optimizing company logistics \\
\hline & $\begin{array}{l}\text { 3. Transfer of information and communication with partner } \\
\text { companies }\end{array}$ \\
\hline & 4. Flexibility of logistics process \\
\hline & 5. Introducing innovation in logistics \\
\hline & 6. Logistics and financial control \\
\hline \multirow[t]{6}{*}{ Human Resources } & 1. Workers satisfaction \\
\hline & 2. Workers motivation \\
\hline & 3. Management and communication \\
\hline & 4. Conflict resolution \\
\hline & 5. Company information system \\
\hline & 6. Company culture \\
\hline
\end{tabular}

Table 2 - Classification of Company Innovation Potential (Adopted from Vacek, et al., 2001)

\begin{tabular}{|l|c|l|}
\hline Classification & Score & \multicolumn{1}{c|}{ Definition } \\
\hline A & $3.50-4.00$ & $\begin{array}{l}\text { The agroindustry company has met all conditions and } \\
\text { innovation potentials to keep growing well. }\end{array}$ \\
\hline AB & $2.50-3.49$ & $\begin{array}{l}\text { The agroindustry company has met some conditions to work } \\
\text { effectively with innovation potentials that are still possible to } \\
\text { be improved. }\end{array}$ \\
\hline B & $1.50-2.49$ & $\begin{array}{l}\text { The agroindustry company has work environment which has } \\
\text { not met the expectation in developing its innovation activity. }\end{array}$ \\
\hline C & $0.50-1.49$ & $\begin{array}{l}\text { The agroindustry company is not conducive or not appropriate } \\
\text { yet for the implementation of innovation activity; a radical and } \\
\text { systematic change is necessary either in the activity or in the } \\
\text { organization. }\end{array}$ \\
\hline
\end{tabular}

\subsection{Stakeholder Survey}

This study uses stakeholder survey to make an assessment towards innovation potential of Gayo coffee agroindustry so that it can be used as reference for the policymakers in directing various activity which are as efforts in building and developing innovation. The stakeholders that are considered competent to give rating are the parties that are directly associated with Gayo coffee agroindustry. In this innovation potential assessment process, a poll was performed of five stakeholders consisting of a lecturer from Gajah Putih University (UGP) Takengon-Aceh, coffee farmer, local coffee entrepreneur, Forestry and Estate Crops Service of Central Aceh Regency, and coffee community. The combined 
opinion was analyzed until a mode of opinion selection is achieved as an innovation potential value to the existence of today's Gayo coffee agroindustry.

\section{RESULT AND DISCUSSION}

The result of innovation potential assessment towards agroindustry of Gayo coffee shows that it occupies AB (Good) classification class with score by 2.72 . it means that agroindustry in this category has fulfilled the preconditions to work more effectively with innovation potential it has. This means that it is in accordance with basic standard which is capable to use changes and innovation to ensure its continuity in the future and even a part of it has gone through certification process to get into more advanced and more developed stages. This condition is very helpful for Gayo coffee agroindustry in developing their innovation potential through organization or human resources development program with various facilities for training and developing the existing individuals' potentials.

In general, it seems that Gayo coffee agroindustry has excellence in logistics, and weakness in the aspect of strategy and planning (Fig. 2). The aspect of strategy and planning occupies category B (Fair, 2.17) which means that agroindustry in current condition has strategy and planning system that is still weak, so that the innovation potential is also still too little to meet the desired expectation. A number of activities are necessary in arranging various future plans, includes various strategy that may be necessary to be prepared for facing sundry possible changes that may occur.

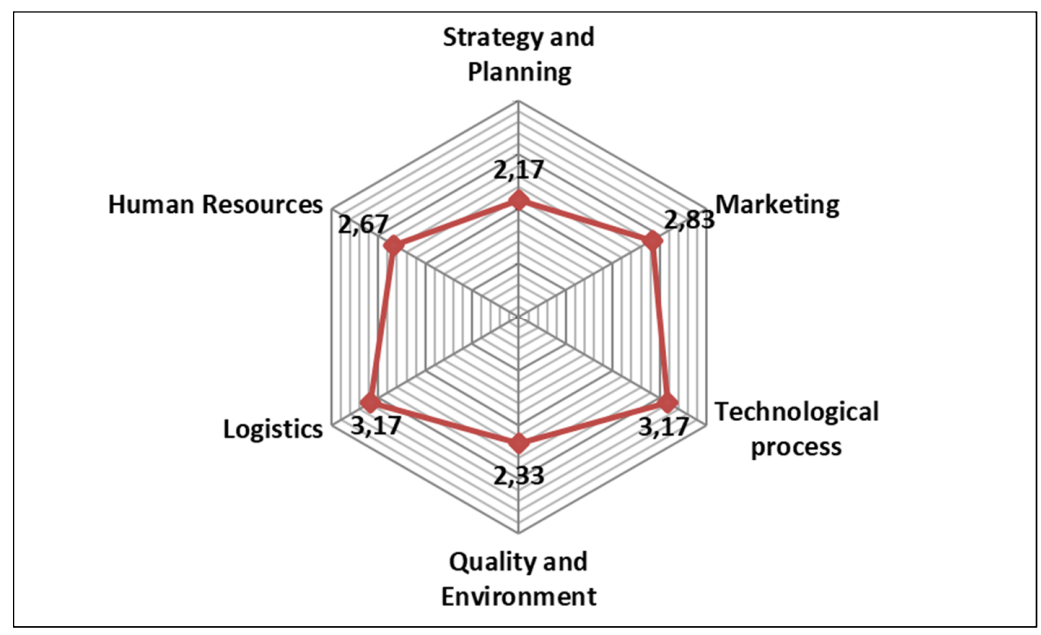

Figure 2 - Chart of Innovation Potential Assessment

Aspect of logistics (3.17), technology (3.17) and marketing (2.83) is quite encouraging because they are in AB class (Good). This is in accordance with the prevailing conditions that all this time, several certifications have been made in 
coffee agroindustry system (since 1992), such as fair-trade, rain-forest, organic, and geographical indications (Taylor, 2005; Raynolds, 2009; Putri, Fariyani and Kusnadi, 2013; ICCRI, 2008; Waroko, et al., 2008; Yantu, et al., 2010; Ardiyani and Erdiansyah, 2012; Fadhil, et al., 2017), that it causes logistical process associated with distribution and marketing become better than other aspects.

In marketing aspect, coffee trading still suffers problem like very high price fluctuations, and tend to be unfair among several agroindustry businessmen (Adam and Ghaly, 2007; Giovannucci and Potts, 2008). Market mechanism is not maximized yet, so the price is determined by other parties (trader) that is relatively cheaper and sometimes the value of the product is not worth the production cost (Bilhak and Maarif, 2014; Mujiburrahman, 2011). As well as the quality and environment aspect, where several problems come up, such as lack of maintenance - especially in pruning and replanting, there are still old plants by about $10 \%$ from total coffee-producing plants -, fertilizing system that does not follow the principles, such as not timely fertilization, excessive or deficient dose, improper composition and fertilizing technique. Those are some problems that need to get treatment (Hasni, 2011; Descroix and Snoeck, 2009).

Meanwhile, aspect of human resources is also low, although it is classified in category $\mathrm{AB}$ (Good, 2.67). However, in this condition, it is realized that the development of comprehension and management of knowledge in coffee cultivation are still less, includes the application of the latest technology and innovation, because they rely more on hereditary knowledge of family (Indra, 2011; Romano, 2009). The other problems associated with human resources are: the development and enhancement of human resources are highly dependent on counseling with lack of facility and limited number of officers; if compared to the area of plantation that has to be addressed (Jaya, 2013; Silitonga, 2008), the lack of human creativity and innovation in processing the products and lack of process industry; particularly the one associated with post-harvest treatment and preliminary treatment, such as fermentation, semi-wet processing, and water usage efficiency (Fatma, 2011; Bilhak and Maarif, 2014). Continuous education and training are necessary for coffee farmers so that the production quality could be better in the future (Walker, 2015; Novita, 2012; Muiburrahman, 2011).

This study has given significant contribution towards the development of Gayo coffee agroindustry, particularly the one related with innovation potential that will be developed. Nevertheless, the study about innovation assessment and innovation audit will continue to evolve in accordance with various advances that lead to finding the best solution in facing global competition. An industry (including agro-industry) is always demanded to evaluate how far the corporation capability is to survive and evolve. Hence, application for innovation potential assessment in Gayo coffee agroindustry become one of research contributions in mapping ways for developing agroindustry innovation to become more favourable. 


\section{CONCLUSION}

Innovation potential of Gayo coffee agroindustry is good enough to continue to be developed by considering the current reality. Many efforts of creating possible condition that will allow innovation activity to grow in the form of work and program in Gayo coffee agroindustry must become serious concerns, so the potential of innovation improvement and development can continue to grow and evolve from time to time. The involvement of various parties, especially local governor, college, related agencies, and extension agency, to synergize in supporting the development of innovation, is necessary. Concerns that are most in need of early treatment are aspect of strategy and planning, human resources aspect, and also quality and environment aspect. These three aspects got low score in innovation potential assessment of Gayo coffee agroindustry, compared to other aspects that have shown better progress. Theoretically, innovation potential assessment is noteworthy for the continuity of an industry, because the condition of the industry innovation potential is a space for development that impacts in competitiveness, and moreover, it promises industry sustainability in facing global challenge.

\section{ACKNOWLEDGMENTS}

The authors thank and highly appreciate the local government of Central Aceh Regency and Bener Meriah Regency in Aceh Province for their support in performing this research. And also to the Directorate General of Higher Education, Ministry of Research Technology and Higher Education, Republic of Indonesia.

\section{REFERENCES}

Adam, M. and Ghaly, A.E., 2007. Maximizing Sustainability of the Costa Rican Coffee Industry. Journal of Cleaner Production, 15(17), pp.1716-1729.

Alkadri, A., 1999. Tiga Pilar Pengembangan Wilayah [Three Pillars of Regional Development]. Jakarta: BPPT.

Ardiyani, F. and Erdiansyah, N.P., 2012. Sertifikasi Kopi Berkelanjutan di Indonesia [Sustainability of Coffee Certification in Indonesia]. Warta Pusat Penelitian Kakao dan Kopi Indonesia, 24(2), pp.21-25.

Baumgartner, J., 2010. The Way of the Innovation Master. JPB, Bwiti bvba. Belgium: Erps-Kwerps.

Bilhak, A. and Maarif, S., 2014. Pengembangan Agribisnis Kopi dalam Kerangka Pembangunan Ekonomi Wilayah di Kabupaten Aceh Tengah [Development of Coffee Agribusiness in the Framework of Regional Economy Development in Central Aceh Regency]. Jurnal Teknik Perencanaan Wilayah Kota, 3(2), pp.254-261. 
Chang, J.C., 2013. Strengthening Value Innovation Potential - A Study of Innovation- Oriented Industry in Taiwan. International Journal of Advancements in Computing Technology (IJACT), 5(4), pp.882-889.

De Prato, G., Nepelski, D. and Piroli, G., 2015. Innovation Radar: Identifying Innovations and Innovators with High Potential in ICT FP7, CIP \& H202O Projects. Seville: JRC-IPTS.

Descroix, F. and Snoeck, J., 2009. Environmental Factors Suitable for Coffee Cultivation. In: J.N. Wintgents, ed. 2009. Coffee: Growing, Processing, Sustainable Production. Weinheim: WILEY-VCH. pp. 168-176.

Ezell, S., Ogilvie, T. and Rae, J., 2007. Seizing the White Space: Innovative Service Concepts in the United States. Technology Review 205/2007, Takes. Helsinki, Finland: the Finnish Funding Agency for Technology and Innovation.

Fadhil, R., Maarif, M. S., Bantacut, T. and Hermawan, A., 2017. Model Strategi Pengembangan Sumber Daya Manusia Agroindustri Kopi Gayo dalam Menghadapi Masyarakat Ekonomi ASEAN [The Model of Strategy for Human Resource Development Gayo Coffee Agro-industry in the ASEAN Economic Community]. Jurnal Manajemen Teknologi, 16(2), pp.141-155.

Fatma, Z., 2011. Analisis Fungsi Produksi dan Efisiensi Usaha Tani Kopi Rakyat di Aceh Tengah [Analysis of Production Function and Efficiency of Local Coffee Farming in Central Aceh]. Ph. D. Central Library of Bogor Agricultural University.

Giovannucci, D. and Potts, J., 2008. Seeking Sustainability: COSA Preliminary Analysis of Sustainability Initiatives in the Coffee Sector. Winnipeg, Canada: Commitee on Sustainability Assessment.

Goffin, K. and Mitchell, R., 2005. Innovation Management: Strategy and Implementation Using the Pentathlon Framework. New York: Palgrave Macmillan.

Gray, A., Boehlje, M., Amanor-Boadu, V. and Fulton, J., 2004. Agricultural Innovation And New Ventures: Assessing The Commercial Potential. American Journal of Agricultural Economics, 86(5), pp.1322-1329.

Hasni, D., 2011. Designing a quality management framework in coffee industry: A literature study of improvement of Arabica coffee as specialty coffee in Indonesia. Ph. D. University of Kassel and University Applied Scince Fulda.

ICCRI, 2008. Panduan Budidaya dan Pengolahan Kopi Arabika Gayo [Guidebook of Gayo Arabica Coffee Cultivation and Processing]. Jakarta (ID): CV Azrajens Mayuma.

Indra, I., 2011. Penentuan Skala Usaha dan Analisis Efisiensi Ekonomi Usaha Tani Kopi Rakyat di Kabupaten Aceh Tengah [Determination of Business Scale and Economic Efficiency Analysis of Local Coffee Farming in Central Aceh Regency]. Agrisep, 12(1), pp.1-8. 
International Coffee Organization, 2011. Annual Review 2011, London, UK: International Coffee Organization.

Jaya, R., 2013. Model Pengelolaan Pasokan dan Risiko Mutu Rantai Pasok Kopi Gayo [Supply Management Model and Quality Risk of Coffee Supply Chain]. Jurnal Teknologi dan Industri Pertanian Indonesia, 5(3), pp.24-32.

Jiřinová, K. and Scholleová, H., 2015. Evaluation of Innovation Potential. In: University of Economics, Prague, 9th International Days of Statistics and Economics, Prague, Czech Republic, 10-12 September 2015, Prague: Malandrium (MSED).

Khanapuri, V.B., Soni, P. and Sharma, S., 2011. Assessing Value Innovation potential of Indian Organization. In: SZABIST Dubai \& International Forum of Management Scholars, International Conference on Technology and Business Management ICTBM-11, Dubai, United Arab Emirates, 28-30 March 2011, Dubai: SZABIST \& INFORMS.

Maulana, I., 2013. Hubungan Antara Potensi Kompetensi Komunitas Dengan Kapasitas Komunitas Pada Kelompok Usaha Tani Kecamatan Lembang, Kabupaten Bandung Barat. [Relationship between Community Competence Potential and Community Capacity on Corporate Farming in Lembang District, West Bandung Regency]. Jurnal Perencanaan Wilayah dan Kota, 24(3), pp.189202.

MERIT (Maastricht Economic and social Research and training centre on Innovation and Technology), 2008. European Innovation Scoreboard 2008 Comparative Analysis of Innovation Performance. Maastricht: MERIT.

Mosher, A.T., 1966. Getting Agricultural Moving. New York: Free Press.

Mujiburrahman, M., 2011. Sistem Jaringan Pasok dan Nilai Tambah Ekonomi Kopi Organik (Studi Kasus di KBQ Baburrayan Kabupaten Aceh Tengah) [Supply Network System and Economic Value-Added of Organic Coffee (Case study at KBQ Baburrayan, Central Aceh Regency)]. Agrisep, 12(1), pp.1-10.

Novita, E., 2012. Desain proses pengolahan pada agroindustri kopi robusta menggunakan modifikasi teknologi olah basah berbasis produksi bersih [Design of Processing on Robusta Coffee Agroindustry by Using Wet-Process Technology Modification based on Clean Production]. Ph. D. IPB Graduate School, Department of Natural Resources and Environmental Management.

Parshukov, D.V., Khodos, D.V., Pyzhikova, N.I., Ivanovna, K.E. and Yuryevna, V.E., 2015. Tools for Assessment of Innovation Potential of the Business Environment Development in the Region. Biosciences Biotechnology Research Asia, 12(3), pp. 2983-2994.

Putri, M.A., Fariyani, A. and Kusnadi, N., 2013. Struktur dan Integrasi Pasar Kopi Arabika Gayo di Kabupaten Aceh Tengah dan Bener Meriah [Market 
Structure and Integration of Gayo Arabica Coffee in Central Aceh Regency and Bener Meriah Regency]. Buletin RISTRI, 4(1), pp.47-54.

Raynolds, L.T., 2009. Mainstreaming Fair Trade Coffee: From Partnership to Treaceability. World Development, 37(6), pp.1083-1093.

Rogers, E., 2003. Diffusion of Innovation. New York: Free Press.

Romano, R., 2009. Kajian Sistem Agribisnis Kopi Organik di Daerah Pegunungan Gayo [Study of Agribusiness Syestem of Organic Coffee in Gayo Mountain Area]. Jurnal Aplikasi Manajemen, 7(1), pp.21-33.

Sabadka, D., 2012. Innovation Potential Metrics. Annals-International Journal of Engineering, 10(3), pp.449-455.

Scarlat, C., Alexe, C. and Scarlat, E.I., 2011. Assessing the Firm's Innovation Potential: A Romanian Case Study. Management and Production Engineering Review, 2(4), pp.57-65.

Silitonga, C.M., 2008. Analisis keunggulan bersaing kopi Arabika Gayo organik di Indonesia [Competitive Advantage Analysis of Arabica Gayo Organic Coffee]. Ph. D. Medan: Universitas Terbuka.

Špaček, M. and Štěpán, M., 2013. Designing New Business Model As A Breakthrough Innovation For Competitive Advantage Creation. In: University of Economics, Prague, 7th International Days of Statistics and Economics, Prague, Czech Republic, 19-21 September 2013, Prague: Malandrium (MSED).

Taylor, P.L., 2005. In the Market but not of it: Fair Trade Coffee and Forest Stewardship Council Certfication as Market-based Social Change. World Development, 33(1), pp.129-147.

Vacek, J., Vacík, E., Skalický, J. and Šlechtová, Y., 2001. Map of the Company Innovation Potential. Prague: Faculty of Economics, University of West Bohemia, Czech Republic.

Walker, H., 2015. Kopi, Cooperatives \& Compliance: A Case Study of Fair Trade in Aceh, Indonesia. Ph. D. School of Geography, Environment \& Earth Scinece, Victoria University of Wellington.

Waroko, T.K., Van Schalkwyk, H.D., Alemu, Z.G. and Ayele, G., 2008. Producer Price and Price Transmission in a Deregulated Ethiopian Coffee Market. Agrecon, 47(4), pp.492-508.

Yantu, M.R., Bambang, J., Hermanto, S., Isang, G. and Setia, H., 2010. Integrasi pasar kakao biji perdesaan Sulawesi Tengah dengan pasar dunia [Integration of Cocoa Beans Market in Central Sulawesi Rural Area to the World Markets]. Jurnal Agro Ekonomi, 28(2), pp.201-225.

Zemtsov, S., 2014. Assessment of Innovation Potential for Russian Regions. In: ERSA, ERSA's Annual Conference 2014, London, 1 December 2014. Available at SSRN: <http://ssrn.com/abstract=2594351> [Accessed 10 October 2017]. 


\section{ABOUT ABOUT AUTHORS}

Rahmat Fadhil, STP., M.Sc., senior lecturer at Department of Agricultural Engineering, Faculty of Agriculture, Syiah Kuala University, Banda Aceh, Indonesia, e-mail: rahmat.fadhil@unsyiah.ac.id.

Prof. Dr. Ir. M. Syamsul Maarif, M.Eng., Dipl. Ing., DEA., professor at Business School, Bogor Agricultural University (IPB), Bogor, Indonesia.

Dr. Ir. Tajuddin Bantacut, M.Sc., associate professor at Department of Agroindustrial Technology, Faculty of Agricultural Engineering and Technology, Bogor Agricultural University (IPB), Bogor, Indonesia.

Dr. Ir. Aji Hermawan, MM., assistant professor Business School, Bogor Agricultural University (IPB), Bogor, Indonesia.

(C) 2017 by the authors. Submitted for possible open access publication under the terms and conditions of the Creative Commons Attribution (CC-BY) license (http://creativecommons.org/licenses/by/4.0/). 